\title{
Airpower in the Union of South Africa's First World War campaign in German South West Africa
}

\section{Antonio Garcia*}

\begin{abstract}
During the Great War, aircraft were used primarily for reconnaissance and artillery spotting. The Union of South Africa's First World War campaign in German South West Africa (GSWA) allowed for South Africa's first employment of military aeroplanes in conventional warfare. The creation and employment of the South African Aviation Corps (SAAC) within the Union Defence Force (UDF) provided ground forces with a substantial force multiplier in terms of forward reconnaissance. The aerial reconnaissance allowed General Louis Botha and his subordinate commanders to gain a better understanding of the tactical picture and facilitated the battle concept. This paper discusses the role and impact of aerial operations during the GSWA campaign. The campaign was characterised by sweeping envelopments which were executed by the Union's commandos. During the latter part of the campaign aeroplanes provided the UDF with intelligence in terms of the location and concentration of German forces, which assisted in their final encirclement.
\end{abstract}

Keywords: German South West African campaign; Union Defence Force; airpower; First World War.

\section{Opsomming}

Gedurende die Eerste Wêreldoorlog was vliegtuie hoofsaaklik gebruik vir verkenningsdoeleindes, en om vuurleiding te gee vir artillerie. Die eerste keer wat die Unie van Suid-Afrika militêre vliegtuie aangewend het in 'n konvensionele rol, was tydens die veldtog in Duits Suidwes-Afrika (DSWA). Die stigting en operasionele aanwending van die Suid-Afrikaanse Vliegkorps, as deel van die Unieverdedigingsmag (UVM), het die magstruktuur en aanwending van die Suid-Afrikaanse troepe ter velde positief beïnvloed, veral in terme van die vergroting van die operasionele verkenningsektor. Sodoende het Generaal Louis Botha en sy stafoffisiere 'n beter

* Antonio Garcia is a PhD candidate at Stellenbosch University, Faculty of Military Science, under the supervision of Professor Ian van der Waag. An earlier version of this paper was presented at the Great War in Africa Conference, hosted by Stellenbosch University in 2015. He is currently preparing a publication, The First Campaign Victory of the Great War (Helion Publishers, Solihull, forthcoming, 2019). Email address: antoniogarcia81@yahoo.com. I would like to thank Evert Kleynhans and Will Gordon for their assistance in translating the abstract of this paper into Afrikaans.

How to cite this article: A. Garcia, "Airpower in the Union of South Africa's First World War Campaign in German South West Africa", Historia, 62, 2, November 2017, pp 1-26.

http://dx.doi.org/10.17159/2309-8392/2017/v62n2a1

Copyright: (CThe Author(s). Published under a Creative Commons Attribution Licence. 
taktiese waardering van die gevegsfront gekry, wat 'n daadwerklike invloed op die meegaande Suid-Afrikaanse gevegsontwerp gehad het. Hierdie artikel bespreek die rol en impak van lugoperasies tydens die veldtog in DSWA. Die veldtog was gekenmerk deur operasionele omsingelings wat op 'n groot skaal uitgevoer was deur die UVM se kommando's. Teen die einde van die veldtog het lugverkenning gehelp om die ligging en sterkte van die Duitse magte vasgestel, wat die finale omsingelingsaanval van die UVM vergemaklik het.

Sleutelwoorde: Duits Suidwes-Afrika veldtog; Unieverdedigingsmag; lugkrag; Eerste Wêreldoorlog.

\section{Introduction}

The industrial revolutions of the nineteenth and early twentieth century ushered in a new era of technological innovation that revolutionised the way war was fought. The early twentieth century brought forward scientific breakthroughs which saw warfare take to the skies. In August 1914, the First World War commenced and ground operations were focused on massing superior forces at critical points in attempts to invade or defend the respective territories.

The European powers were soon locked in a war of attrition on the Western Front where manoeuvre space was exhausted and the defensive position became favoured over the offensive which assumed the majority risk. ${ }^{1}$ The Great War became static because mobile operations soon turned out to be impractical with the preponderance of trenches and defensive obstacles on the Western Front. ${ }^{2}$ Extending over 600 kilometres from the North Sea to the Franco-Swiss border, the Western Front saw extensive operations and high intensity attrition battles. During the stalemate on the Western Front, military aviation became the only option to conduct mobile reconnaissance and artillery spotting. ${ }^{3}$ Furthermore, military aviation also demonstrated the potential for aerial bombardment. ${ }^{4}$

The First World War took on a different character and shape in the varying operational theatres and where the Western Front was reduced to a mass stalemate, the colonial conflicts of the Great War were largely executed over large and open spaces. Great Britain requested the Union of South Africa to take control of the ports of Lüderitzbucht and Swakopmund on the coast of GSWA as part of the imperial

1. D.E. Showalter, "Manoeuvre Warfare: The Eastern and Western Fronts", in H. Strachan, (ed.), The Oxford Illustrated History of the First World War (Oxford University Press, Oxford, 1998), p 46.

2. D.T. Zabecki, The German 1918 Offensives: A Case Study in the Operational Level of War (Routledge, New York, 2006), p 46.

3. A. Whitmarsh, "British Army Manoeuvres and the Development of Military Airpower 1910-1913", War in History, 14, 3 (2007), p 325.

4. J.H. Morrow, "The War in the Air", in *Strachan, Oxford Illustrated History, p 268; C. Blount, "Modern Airpower and the 1916 Arab Revolt: What can the Modern Airman do to Counter Lawrence of Arabia", Air and Space Power Journal, 23, 3 (2009), p 21. 
strategy, thus preventing Germany from using these ports to refuel, re-supply and repair German warships. In addition, the British strategy required the capture of wireless stations in Windhoek, Lüderitzbucht and Swakopmund, which were able to provide and maintain communications between Berlin and German warships at sea. ${ }^{5}$ The control of the ports on the coast of southern Africa was vital to British geostrategy. ${ }^{6}$

The Union of South Africa invaded GSWA as an extension of imperial war aims and fought a very different campaign in comparison to the static warfare on the Western Front. The UDF applied a highly mobile campaign against the German colonial forces (Schutztruppe) in GSWA. The open spaces of the Namib Desert and the coastal plateau spreading inland, provided an ideal platform for rapid and manoeuvre warfare. ${ }^{7}$

The use of aircraft in the German South West African campaign assisted the ground operations in providing up-to-date reconnaissance. During the First World War aerial reconnaissance was used to facilitate the operational planning process and the commander's decision-making cycle. ${ }^{8}$ The historiography of the campaign provides limited focus on the element of air operations.

Whereas the first literature to appear on the campaign had a strong British historiographical tradition, ${ }^{9}$ there has also been a significant modern wave of publications revising this older methodology. ${ }^{10}$ Furthermore, there is a growing body

5. $\quad$ G. L'ange, Urgent Imperial Service (Ashanti, Johannesburg, 1991), p 7.

6. Department of Defence Archives (hereafter DOD Archives), Diverse (hereafter D), Box 8, 37, Report on the Military Situation in South Africa, 20 August 1910.

7. See, A. Garcia, 'A Manoeuvre Warfare Analysis of South Africa's 1914-1915 German South West African Campaign', Scientia Militaria, 45, 1 (2017).

8. J. Steckfuss, Eyes All over the Sky: Aerial Reconnaissance in the First World War (Casemate, Oxford, 2016), p 2.

9. See, for example Anon., Union of South Africa and the Great War, 1914-1918: Official History (Government Printer, Pretoria, 1924); J.J. Collyer, The Campaign in German South West Africa, 1914-1915 (Government Printer, Pretoria, 1937); H.F. Trew, Botha Treks (Blackie \& Son, London, 1936); M.E. Ritchie, With Botha in the Field (Longmans, London, 1915); W. Whittal, With Botha and Smuts in Africa (London: Cassell, 1917); H.F.B. Walker, A Doctor's Diary in Damaraland (Edward Arnold, London, 1917); D.E. Reitz, Trekking On (Travel Book Club, London, 1947); P.K.J. Robinson, With Botha's Army (Allen \& Unwin, London, 1916); E. Dane, British Campaigns in Africa and the Pacific 1914-1918 (Hodder \& Stoughton, London, 1919); W.W. O'Shaughnessy and W.S. Rayner, How Botha and Smuts Conquered German South West (Simpkin, London, 1916).

10. See, L'ange, Urgent Imperial Service; B. Nasson, Springboks on the Somme (Penguin, Johannesburg, 2007); T. Couzens, The Great Silence (Sunday Times, Johannesburg: 2014); A.M. Grundlingh, Fighting Their Own War: South African Blacks and the First World War (Ravan Press, Johannesburg, 1988); J. Stejskal, The Horns of the Beast: The Swakop River Campaign and World War I in South West Africa, 1914-1915 (Helion, Solihull, 2014); I. Gleeson, The Unknown Force: Black, Indian and Coloured Soldiers through Two World Wars (Ashanti, Johannesburg, 1994); D. Williams, Springboks, Troepies and Cadres: Stories of the South African Army 1912-2012 (Tafelberg, Cape 
of contemporary academic literature which re-evaluates various and specific aspects of the campaign. ${ }^{11}$

The participation of indigenous African people in the campaign in GSWA remains an under-researched theme. Whereas there is considerable focus on the role of the South African Native Labour Contingent and the Cape Coloured Corps ${ }^{12}$ in South Africa's First World War campaigns in German East Africa, France and Palestine, the participation of Africans, Coloureds and Indians in GSWA requires further research. The involvement of people of colour in the campaign in GSWA is perhaps more difficult to trace because they were not organised into independent units, but were rather incorporated into various brigades, regiments and sections as drivers, auxiliaries, scouts, assistants and batmen. ${ }^{13}$ Records on the strength of units indicate that there were eight people of colour attached to the SAAC during the final advance. ${ }^{14}$

Town, 2012); A. Cruise, Louis Botha's War: The Campaign in German South West Africa 1914-1915 (Zebra, Cape Town, 2015); H. Strachan, The First World War, Vol 1: To Arms (Oxford University Press, Oxford, 2001); T.R. Ungleich, "The Defence of German South West Africa during World War I", MA thesis, University of Miami, 1974; B. Farwell, The Great War in Africa 1914-1918 (Norton, New York, 1986); I. Van der Waag, A Military History of Modern South Africa (Jonathan Ball, Johannesburg, 2015); A. Delport, "Boks and Bullets, Coffins and Crutches': An Exploration of the Body, Mind and Places of 'Springbok' South African Soldiers in the First World War', MA dissertation, Stellenbosch, 2015; B. Nasson, World War 1 and the People of South Africa (Tafelberg, Cape Town, 2014); A. Samson, World War I in Africa: The Forgotten Conflict among European Powers (I.B. Taurus, London, 2013).

11. R.C. Warwick, "The Battle of Sandfontein: The Role and Legacy of Major General Sir Henry Timson Lukin", Scientia Militaria, SA Journal of Military Studies, 34, 2 (2006); I. Van der Waag, "The Battle of Sandfontein, 26 September 1914: South African Military Reform and the German South West Africa Campaign, 1914-1915", First World War Studies, 4, 2 (2013); E. Kleynhans, "A Critical Analysis of the Impact of Water on the South African Campaign in German South West Africa, 1914-1915", Historia, 61, 2 (2016); A. Garcia, "Manoeuvre Warfare in the South African Campaign in German South West Africa during the First World War", MA dissertation, University of South Africa, 2015.

12. See A. Grundlingh, Participation and Remembrance: South African Black and Coloured Troops in the First World War, 1914-1918 (Sun Press, Stellenbosch, 2014); B. Nasson, "Delville Wood and South African Great War Commemoration", English Historical Review, 119, 480 (2004); Gleeson, The Unknown Force; W.M. Bisset, 'Unexplored Aspects of South Africa's First World War History', Scientia Militaria, 6, 3 (1976). A.I. Venter, Coloured: A Profile of Two Million South Africans in Cape Town (Human \& Rousseau, Cape Town, 1974); Grundlingh, Fighting Their Own War; I.D Difford, The Story of the 1st Battalion Cape Corps, 1915-1919 (Hortons, Cape Town, 1920); DOD Archives, Box 2517, South African Native Labour Contingent, Commemoration of the 'missing' SANLC, 1926.

13. DOD Archives, Adjutant General (hereafter AG), 1914-1921 $\mathrm{G} / 42 / 25$, Correspondence with Defence Headquarters regarding allocation of batmen, 1914; DOD Archives, Secretary of Defence (hereafter SD), Box 252, Strength of Units 'Natives' attached to the various Brigades, July 1915.

14. DOD Archives, SD, Box 252, Strength of Units during the Final Advance in German South West Africa, July 1915. 
Despite the growing body of literature on the strategic operations and tactical aspects of the campaign, there are limited sources which provide in-depth analysis on the juxtaposition between ground and air operations in GSWA. ${ }^{15}$ This article aims to address the lack of focus on air operations by providing a detailed discussion on the use of aerial reconnaissance and rudimentary bombing missions in support of ground operations in GSWA in 1915.

The development of the South African Aviation Corps (SAAC), which was established on 19 January $1915,{ }^{16}$ was slower in comparison to that of the European powers that had to develop in accordance with the growing mobilisation of air assets. During 1915 military aviation, facilitated by new technological innovation, quickly developed the fighter plane and pilot. ${ }^{17}$ The narrative of airpower throughout history involves the central tenet of technological development and progress. ${ }^{18}$ The total mobilisation of the Great War resulted in a stalemate where numbers and mass were the main focus and appeared to be the only solution. The application of airpower by the UDF during the campaign in GSWA was on a much lower and limited level when compared to that of the European theatre of operations which mirrored the intensity of the conflict. Airpower in GSWA was introduced as a means of aerial reconnaissance. This paper postulates that aerial reconnaissance in the campaign facilitated the offensive manoeuvres executed by the UDF which ultimately led to the surrender of the German forces. The article commences with a discussion on the context and background of airpower in South Africa, followed by a close examination on ground and air operations in the German South West African campaign.

\section{Airpower, the Great War and the Union of South Africa}

Initial interest in aviation in terms of air balloons was initiated by the Royal Engineers in the 1860s. The Royal Flying Corps (where the first South African pilots were trained) replaced the Air Battalion on 11 April 1912 and shortly after the Royal Naval Air Service broke away from the Royal Flying Corps in July 1914. The development of aeroplanes resulted in their operational use in the 1911-12 Italo-Turkish War and in the 1912-13 Balkan War. The British Army manoeuvres and training exercises from 1912 onwards included the use of aircraft and it was determined that the effective use

15. W.A. Raleigh and H.A. Jones, The War in the Air: Being the Story of the Part Played in the Great of the Royal Air Force (Oxford: Clarendon Press, Oxford, 1922); S. Monick, "The Third Man: Willy Trück and the German Air Effort in South West Africa in World War I", Military History Journal, 5, 3 (1981); J.O.E.O. Mahncke, "Aircraft Operations in the German Colonies, 1911-1916: The Fliegertruppe of the Imperial German Army", Military History Journal, 12, 2 (2001); K.R. Van der Spuy, Chasing the Wind (Books of Africa, Cape Town, 1966); T. Dedering, “Air Power in South Africa, 1914-1939”, Journal of Southern African Studies, 31, 3 (2015).

16. The South African Air Force was established on 1 February 1920.

17. Morrow, "The War in the Air", in Strachan, Oxford Illustrated History, p 269.

18. S.H. Lukasik, "Insurgent Airpower in Historical Perspective: An Introduction and Prospectus of Research", The Historian, 74, 2 (2012), p 225. 
of aeroplanes would become instrumental to attain victory. ${ }^{19}$ Leo Amery ${ }^{20}$ mentioned the importance of aerial reconnaissance for static armies one year before the First World War commenced. ${ }^{21}$

At the beginning of the First World War, there was a substantial focus on the development of the aeroplane as a weapon of war. The initial use of the aeroplane during the Great War was for the purpose of reconnaissance in direct support of the ground forces. This later evolved into strategic reconnaissance. The reconnaissance planes were accompanied by combat planes with the aim of protecting the reconnaissance planes. This in turn led to the creation of planes to destroy the protector plane and the progression of aerial combat. ${ }^{22}$ Despite the development of one-on-one and formation aerial combat, masses of air patrols struggled to check air reconnaissance flights. ${ }^{23}$

The Union's pilots in GSWA were not required to function as fighter pilots because the German aeroplanes were out of commission by the time the SAAC was deployed. The development of the Union's airpower in GSWA was on a much more limited scale when compared to the European theatre and the main purpose of the SAAC remained reconnaissance which directly assisted the ground forces. ${ }^{24}$

Amery was of the opinion that aeroplanes would be of far greater value in theatres of operations where there were not high concentrations of troops and where extended expanses of terrain and limited communications were combined with highly mobile operations. ${ }^{25}$ The GSWA campaign made for an interesting case study to test Amery's hypothesis because it proved to be one of manoeuvre and vast distances.

One of the functions of airpower is to provide current information to the commander throughout the operational area. The ability to find the enemy then allows the commander to "fix" the enemy by which its freedom of action and mobility is minimised. The domination of the skies and the ability to locate the enemy in turn facilitates complete situational awareness for the commander. ${ }^{26}$

19. Whitmarsh, "British Army Manoeuvres", p 327.

20. Leo Amery was a war correspondent during the South African War. He later edited the Times History of the South African War.

21. K.P. Epstein, "Imperial Airs: Leo Amery, Airpower and Airpower, 1873-1945", The Journal of Imperial and Commonwealth History, 38, 4 (2010), p 575.

22. J.A. Hennessy, "Men and Planes of World War 1 and History of Lafayette Escadrille", Air Power History, 61, 2 (2014), p 21.

23. A.D. Harvey, "Air Warfare in Perspective", Air Power History, 60, 3, 2013, p 9.

24. Monick, "The Third Man", p 1; Mahncke, "Aircraft Operations in the German Colonies", p 2; Trew, Botha Treks, p 152; L'ange, Urgent Imperial Service, p 118.

25. Epstein, "Imperial Airs", p 578, p 579.

26. Blount, "Modern Airpower and the 1916 Arab Revolt", p 53. 
General Louis Botha ${ }^{27}$ commented to Lieutenant Kenneth van der Spuy that he was a good pilot and an excellent verkyker (pair of binoculars) referring to the reconnaissance function of the aircraft. Botha went on to say that the knowledge of enemy positions enabled him to move and place his troops accordingly. ${ }^{28}$ The combination of air reconnaissance with the high mobility of the mounted forces in GSWA proved to be effective in the later stages of the campaign. The air reconnaissance allowed the UDF to know where the German forces were deployed and the commando's ${ }^{29}$ mobility allowed for the element of surprise to be achieved. ${ }^{30}$

While locating the opposing force was central to tactical considerations, the pace of the campaign was greatly influenced by logistical considerations and the availability of water resources. ${ }^{31}$ The campaign was characterised by extensive and rapid manoeuvres which were followed by operational pauses which were used to regroup. ${ }^{32}$ Furthermore, the great expanses of GSWA were "mitigated" through the use of aerial reconnaissance which became a force multiplier.

\section{The South African Aviation Corps}

Interest in flying for military purposes and the creation of the SAAC was facilitated by General Christiaan Frederik Beyers who as commandant general of the Active Citizen Force was sent by General Jan Christiaan Smuts ${ }^{33}$ to Britain in 1912 to observe the military manoeuvres and the use of aeroplanes in army operations. On his return, Beyers highly recommended the use aeroplanes in warfare especially for reconnaissance. The 1912 Defence Act allowed for an Aviation Corps to be created under the Active Citizen Force. Smuts was aware of the importance of aerial reconnaissance and put in a considerable effort to expedite the process of deploying the SAAC to the theatre of operations in GSWA. ${ }^{34}$ Smuts was one of the visionaries ${ }^{35}$ who foresaw the remarkable potential of the aeroplane. ${ }^{36}$

27. Botha was the prime minister of the Union of South Africa and the commander-in-chief of the Union expeditionary force in GSWA.

28. L'ange, Urgent Imperial Service, p 267.

29. Commandos were Afrikaner irregular military units in South Africa. They were characterised as having good tactical initiative, marksmanship and equestrian skills despite being undisciplined.

30. Nasson, Springboks on the Somme, pp 63-65.

31. Kleynhans, "A Critical Analysis", p 50.

32. Garcia, "Manoeuvre Warfare", p 113.

33. Smuts was Botha's friend, partner and confidant in political as well as military affairs. Smuts became the minister of defence, mines and interior in 1910.

34. L'ange, Urgent Imperial Service, p 268, p 269.

35. In 1917 Smuts had become a member of the British War Cabinet and promoted the Air Force as a separate wing, removed from the Army. Leo Amery suggested to Smuts that the Air Force should have a separate and independent staff. Smuts and Amery had become friends during the South African War. See Epstein, "Imperial Airs", p 577.

36. Hennessy, "Men and Planes of World War 1", p 16. 
In 1913 the first South African military pilots began their training at the Paterson Aviation Syndicate School (which was later purchased by the UDF), located at Alexanderfontein. Then the candidate pilots did a course at Tempe School before being sent for training at the Royal Flying Corps in the UK. ${ }^{37}$ The initial training course at Alexanderfontein comprised ten candidate pilots as per the memorandum of agreement signed between Smuts and Cecil Compton Paterson. ${ }^{38}$

The South African high commissioner in London negotiated for the acquisition of aeroplanes in October 1914. ${ }^{39}$ While the finalisation of these talks was still under way, Major General Henderson, the officer commanding of the Royal Flying Corps ordered the formation of the SAAC in November 1914 to assist with the South African campaign in GSWA during the Great War. Several types of planes were scrutinised to determine the ideal aircraft for the climate in GSWA. The Henri Farman F-27 was decided upon after which several tests flights were done in France. ${ }^{40}$ The South African pilots who were serving in other theatres during the Great War were recalled to form the SAAC (accompanied by some British officers and soldiers). These pilots included Captain (later Major) Gerard Wallace who became the commander of the Aviation Corps and Lieutenants Clisdal and Carey-Thomas, who were observers. ${ }^{41}$ Also part of the Aviation Corps were the military pilots Lieutenants Kenneth van der Spuy, Gordon Creed, Basil Turner, Cripps, Marthinus Williams and Edwin Emmet.42

During early 1915 Turner and Emmet were sent to the Union of South Africa and GSWA respectively. Turner was assigned the task of recruiting further members for the embryonic Aviation Corps and Emmet was responsible for finding a suitable aerodrome in Swakopmund in GSWA. ${ }^{43}$ In terms of supporting staff, 34 mechanics were transferred from the Royal Naval Air Service to the Union of South Africa. ${ }^{44}$ The

37. Mahncke, "Aircraft Operations in the German Colonies", pp 1, 2; DOD Archives, World War 1 Diaries (hereafter WW1 WD), Box 2, Air/1/1247/204/7/4, Historical record of No. 26 (SA) Squadron and South African Aviation Corps; and Historical record of the South Africa unit of the Royal Flying Corps; L'ange, Urgent Imperial Service, p 269.

38. See, D.P. Tidy, "They Mounted up as Eagles: A Brief Tribute to the South African Air Force", The Military History Journal, 5, 6 (1982).

39. L'ange, Urgent Imperial Service, p 273.

40. DOD Archives, WW1 WD, Box 1, Air 1/1247/204/7/1, Report by Major Wallace on the campaign in German South West Africa, 1915, 21 July 1916; L'ange, Urgent Imperial Service, $\mathrm{p} 269$.

41. DOD Archives, WW1 WD, Box 1, Air 1/1247/204/7/1, Vol. 3, Aviation report on German South West Africa April 1915-1916, War Diary.

42. DOD Archives, WW1 WD, Box 1, Air 1/1247/204/7/1, Report by Major Wallace on the campaign in German South West Africa, 1915, 21 July 1916.

43. DOD Archives, WW1 WD, Box 1, Air 1/1247/204/7/1, Report by Major Wallace on the campaign in German South West Africa, 1915, 21 July 1916; L'ange, Urgent Imperial Service, $\mathrm{p} 269$.

44. DOD Archives, WW1 WD, Box 2, Air/1/1247/204/7/4, Historical record of No. 26 (SA) Squadron and South African Aviation Corps; and Historical record of the South African unit of Royal Flying Corps; DOD Archives, WW1 WD, Box 1, Air 1/1247/204/7/1, Report by Major Wallace on the campaign in GSWA, 1915, 21 July 1916. 
preliminary staff was supplemented by additional pilots and supporting personnel such as observers and logistical administrators.

The SAAC initially comprised four Henri Farmans F-27 and two Blériot Experimental model 2C (B.E.2c) planes. The remaining staff and four of the six aeroplanes (two B.E.2cs and two Henri Farman F-27s) arrived by ship in Walvis Bay on 30 April 1915 and the aircraft were disembarked on 1 May 1915. Two of the Henri Farman's had been damaged as a result of the sea voyage. The first test flight was taken by Van der Spuy in one of the B.E.2c planes on 4 May, ${ }^{45}$ after which the other B.E.2c was tested on 5 May. Both aircraft were declared combat ready by 7 May 1915.46 The first planned task for the newly formed aviation corps was to support operations against Karibib, however the UDF captured Karibib before the SAAC could conduct any reconnaissance missions over the town.

\section{Ground operations in GSWA and the deployment of the SAAC}

The invasion of German South West Africa was initiated in September 1914. The first attempts at invading the country was a cross-border advance which culminated in a bloody nose for the UDF at the Battle of Sandfontein. ${ }^{47}$ The Union of South Africa's entry into the First World War ignited predisposing tensions within the Afrikaner demographic which triggered the Afrikaner Rebellion. ${ }^{48}$ Many Afrikaners did not identify with the British cause and imperial objectives. ${ }^{49}$ The UDF's campaign in GSWA was thus placed on hold until the rebellion was effectively quelled in late 1914.

The invasion plan for GSWA involved amphibious as well as terrestrial invasion lines into the desolate German colony. The amphibious landings took place at Walvis Bay and Lüderitzbucht and the terrestrial invasion crossed the northern border of the Union of South Africa and entered GSWA. The force that landed at Walvis Bay became the Northern Force (later Northern Army) and the amphibious force that landed at Lüderitzbucht (Southern Force) as well as the force groupings (Central and Eastern Force) which executed the cross-country invasion of GSWA, became known as the Southern Army. Botha, who was the prime minister of the Union of South Africa at the

45. DOD Archives, WW1 WD, Box 1, Air 1/1247/204/7/1, Vol. 3, Aviation report on German South West Africa April 1915-1916, War Diary.

46. DOD Archives, WW1 WD, Box 1, Air 1/1247/204/7/1, Report by Major Wallace on the campaign in GSWA, 1915, 21 July 1916. Mahncke gives the first reconnaissance flight on 6 May 1915, see his "Aircraft Operations in the German Colonies", p 3. However, this flight may have indeed been a test flight.

47. For discussion on the Battle of Sandfontein, see Warwick, "The Role and Legacy; and Van der Waag, "The Battle of Sandfontein".

48. Van der Waag, "The Battle of Sandfontein", p 7. See also S. Swart, "The 'Five Shilling Rebellion': Rural White Male Anxiety and the 1914 Boer Rebellion", South African Historical Journal, 56, 1 (2006); and S. Swart, “'Desperate Men' The 1914 Rebellion and the Polities of Poverty", South African Historical Journal, 42, 1 (2000); S. Swart, "'A Boer and his Gun and his Wife are Three Things Always Together': Republican Masculinity and the 1914 Rebellion", Journal of Southern African Studies, 24, 4 (2008).

49. Nasson, Springboks on the Somme, p 10. 
time, a former Anglo-Boer War (South African War) general as well as a commissioned general in the British military, assumed overall command of operations as well as the operational level command of the northern advance. ${ }^{50}$

The operational plan for the advance and invasion of the southern part of GSWA comprised the divergent advances of three different force groupings. The Southern Force landed at Lüderitzbucht, while the Central and Eastern Forces respectively crossed the northern border of the Union of South Africa, upon which they entered GSWA. These three forces constituted the Southern Army and their operations resulted in the capture of Keetmanshoop which restricted the rail movement of the German forces in the south and forced them to the north of the colony. Operations in the south of GSWA were concluded with the Battle of Gibeon and the UDF prisoners of war there were released..$^{51}$ Map 1 below indicates the impact of the initial operations in GSWA until the start of May 1915.

The Northern Army then advanced from Lüderitzbucht in an easterly direction. The northerly advance was constrained by the availability of logistics, water and transport. ${ }^{52}$ The intermediate objective of the northern invasion was Karibib which was a strategic rail link. ${ }^{53}$ The Northern Army captured Karibib on 6 May and Windhoek was taken unopposed on 12 May $1915 .{ }^{54}$ Following the capture of Windhoek the Northern Army took a month and a half operational pause to accumulate the required materiel and logistics required to execute the final advance. 55 Toward the end of May 1915 the SAAC was deployed to the frontlines to conduct aerial reconnaissance

50. DOD Archives, Adjutant General (hereafter AG), 1914-1921, Box 8, G5/305/9199, Commander-in-chief, Government notice for the next issue of the Union Gazette, 18 October 1914.

51. W.A. Dorning, "A Concise History of the South African Defence Force 1912-1987", Militaria, South African Journal for Military Studies, 17, 2 (1987), p 4.

52. L'ange, Urgent Imperial Service, p 244; Anon., Official History, p 32; Whittal, With Botha and Smuts, p 137; Collyer, The Campaign in German South West Africa, 1914-1915, p 23; Kleynhans, "A Critical Analysis", pp 41, 42.

53. Dorning, "A Concise History", p 4.

54. Nasson, Springboks on the Somme, p 74; Anon., Official History, p 40; J. Meintjes, General Louis Botha (Cassel, London, 1970), p 264; Whittal, With Botha and Smuts, p 62; H. Paterson, "First Allied Victory: The South African Campaign in German South-West Africa, 1914-1915”, Military History Journal, 13, 2 (2004), p 6.

55. Strachan, The First World War, p 565; Anon., Official History, p 32. 
in support of the final advance. ${ }^{56}$ The deployment of aircraft in the area of operations was eagerly anticipated. ${ }^{57}$

The first task of the Aviation Corps after assembling their planes was to ensure that there were aerodromes along the axis of advance which would allow the planes to land at the required UDF operating bases. There were already existing aerodromes at Karub and Karibib and the SAAC made minor modifications to the infrastructure to accommodate its aircraft, after which technical and logistical supplies for the aircraft were sent up to these aerodromes on 7 May 1915..$^{58}$ The logistical and transport arrangements for the Aviation Corps were not ideal for the conditions in GSWA. The existing support systems were placed under considerable strain in getting the required spares, which were often lacking, from the maintenance base in Walvis Bay to the front lines. ${ }^{59}$

56. The United Kingdom National Archives (hereafter TNA), ADM 123/144, War Records 1914-1918, General Letters and Proceedings, Walvis Bay, May 1915; DOD Archives, WW1 WD, Box 1, Air 1/1247/204/7/1, Vol. 2, Aviation report on German South West Africa April 1915-1916, Report of Transport Officer; DOD Archives, WW1 WD, Box 1, Air 1/1247/204/7/1, Vol. 10, Aviation report on German South West Africa April 1915-1916, Diary No, 2 kept by Lieutenant Carey-Thomas; DOD Archives, WW1 WD, Box 1, Air 1/1247/204/7/1, Report by Major Wallace on the campaign in German South West Africa, 1915, 21 July 1916.

57. South African National Archives (hereafter SANA), Smuts Papers, Box 112, Major General Thompson: Report on a visit to German South West Africa, 20-27 March 1915.

58. DOD Archives, WW1 WD, Box 1, Air 1/1247/204/7/1, Report by Major Wallace on the campaign in German South West Africa, 1915, 21 July 1916.

59. DOD Archives, WW1 WD, Box 1, Air 1/1247/204/7/1, Vol. 2, Aviation report on German South West Africa, April 1915-1916, Report of Transport Officer. 


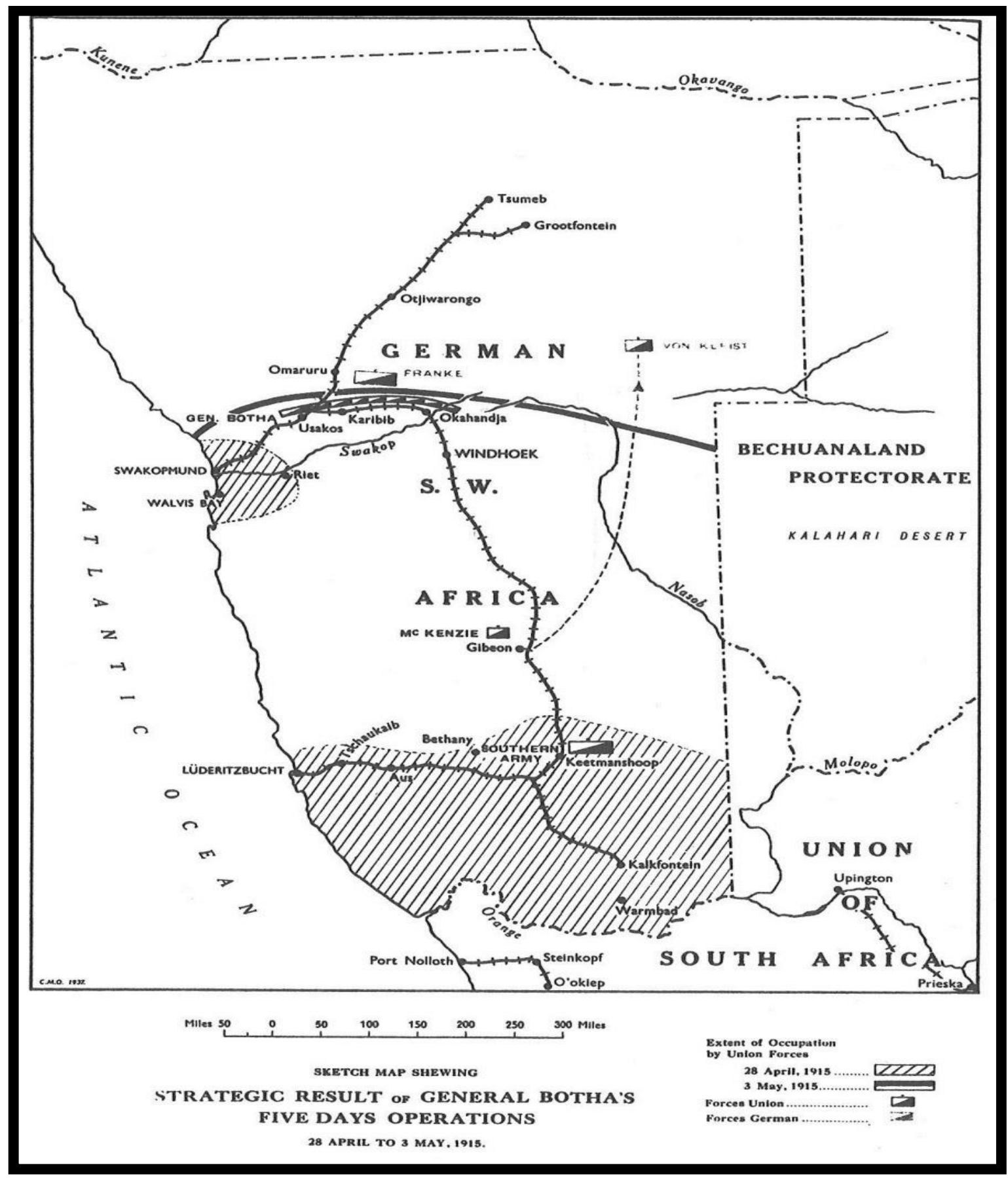

\section{Map 1: Result of the South African actions up to 3 May $1915^{60}$}

On 9 May 1915, Turner and Cripps each flew a B.E.2c to Karub. On 11 May, while moving his aircraft up to the front, Turner crashed his plane at Karub. Van der Spuy conducted the first flight with a Henri Farman on 13 May and after experiencing some minor complications, the aircraft was returned to the workshop for technical adjustments. ${ }^{61}$ Supplies and personnel were sent up from Walvis Bay to Karub and 
Karibib on 12 May with 11 cars and one trailer to support aviation operations at the front. 62

The Union headquarters ordered a reconnaissance flight of Omaruru on 23 May 1915 because the final advance was being planned. ${ }^{63}$ Van der Spuy was sent up from Walvis Bay with a Henri Farman on 25 May 1915 and he landed in Karub the same day. He proceeded to Karibib on 26 May. ${ }^{64}$ The first reconnaissance flight in support of operations was attempted on 27 May but was abandoned due to excessive wind speeds which were thought to compromise the aircraft. ${ }^{65}$ The reconnaissance flight was carried out the following morning and reported that approximately 20 German soldiers had been sighted in and around Omaruru; the remainder of the German forces had evacuated the town. Furthermore, it was extrapolated that the 20 soldiers were planning to evacuate in due course. ${ }^{66}$

On the German side, aircraft were also used for reconnaissance and for rudimentary aerial bombardment. ${ }^{67}$ The German forces had two military pilots, Lieutenant von Scheele and 2nd Lieutenant Fiedler as well as Willie Truck, who was a factory test pilot. 68 Truck was sent to Karibib by the Aviatik Automobil und Flugapparatefabrik aircraft factory in Germany. ${ }^{69}$ On 27 May, Von Scheele crashed his plane and it appears that there was no record of German flights after this date. ${ }^{70}$

Early June 1915 was a time of considerable exploration for the SAAC, during which new and improvised equipment was tested. On 4 and 5 June the aviation support technicians worked on improvised bomb dropping fittings which were installed on the aeroplanes. ${ }^{71}$ It is interesting to note that the American military initially opposed the

62. DOD Archives, WW1 WD, Box 1, Air 1/1247/204/7/1, Vol. 10, Aviation report on German South West Africa April 1915-1916, Diary No. 2 kept by Lieutenant CareyThomas.

63. DOD Archives, SD, Box 252, 17138, Reports of Force Commanders in German South West Africa, Despatch No. 4 by General Botha covering the period 15 May to 18 July 1915.

64. DOD Archives, WW1 WD, Box 1, Air 1/1247/204/7/1, Report by Major Wallace on the campaign in German South West Africa, 1915, 21 July 1916; DOD Archives, WW1 WD, Box 1, Air 1/1247/204/7/1, Vol. 3, Aviation report on German South West Africa April 1915-1916, War Diary.

65. DOD Archives, WW1 WD, Box 1, Air 1/1247/204/7/1, Vol. 10, Aviation report on German South West Africa, April 1915-1916, Diary No. 2 kept by Lieutenant CareyThomas; DOD Archives, WW1 WD, Box 1, Air 1/1247/204/7/1, Report by Major Wallace on the campaign in German South West Africa, 1915, 21 July 1916.

66. DOD Archives, WW1 WD, Box 1, Air 1/1247/204/7/1, Report by Major Wallace on the campaign in German South West Africa, 1915, 21 July 1916.

67. L'ange, Urgent Imperial Service, p 118.

68. Mahncke, "Aircraft Operations in the German Colonies", p 1.

69. Monick, "The Third Man", p 1.

70. L'ange, Urgent Imperial Service, pp 268, 269.

71. DOD Archives, WW1 WD, Box 1, Air 1/1247/204/7/1, Vol. 10, Aviation report on German South West Africa, April 1915-1916, Diary No. 2 kept by Lieutenant CareyThomas. 
idea of aerial bombing, insisting that reconnaissance was the primary function of the aeroplane. ${ }^{72}$ On 6 June the Henri Farman plane was flown to 12500 feet which was a record by South African standards. ${ }^{73}$ The aeroplanes used at the beginning of the Great War had open cockpits and could reach a maximum altitude of 12000 feet. The development of aeronautical technology during the First World War improved the limits of aircraft immensely and this surge of development produced planes which could travel up to 130 miles per hour and reach altitudes of up to 20000 feet. $^{74}$ The SAAC thus did well in reaching 12500 feet with the aeroplanes they had available. On 7 June the bomb-dropping fittings were tested, dropping petrol bombs from 500 feet, however the test proved unsuccessful. ${ }^{75}$

Two more Henri Farmans arrived in Walvis Bay on 7 June and Wallace ordered them to be assembled and sent up to the front for the UDF's final advance. While the planes were brought up from Walvis Bay, Van der Spuy conducted a second reconnaissance of Omaruru on 10 June and confirmed the same information as the first reconnaissance. Furthermore, two 16 pound bombs were dropped on the position at Omaruru. The bomb fittings were reported to be in good working order. ${ }^{76}$

\section{The final advance}

Botha had managed to accumulate sufficient stores by mid-June to carry the campaign to completion. The final operations involved a central advance and an extensive double envelopment which aimed to cut off and encircle the German forces. For the most part the central column was comprised of infantry formations commanded by Brigadiers $\mathrm{H}$. Lukin and P.S. Beves. The pincer movements were executed by Brigadier Generals C. Brits and M.W. Myburgh who commanded the 1st Mounted and 2nd Mounted Brigades respectively. Brits and the 1st Mounted Brigade took a wide enveloping route in capturing Etosha Pan and Namutoni. Then Myburgh's forces captured Grootfontein and Tsumeb in a wide envelopment. ${ }^{77}$

72. Hennessy, "Men and Planes of World War 1", p 21.

73. DOD Archives, WW1 WD, Box 1, Air 1/1247/204/7/1, Vol. 3, Aviation report on German South West Africa, April 1915-1916, War Diary.

74. D.R. Baucom, "Wakes of War: Contrails and the Rise of Air Power 1918-1945, Part 1, Early Sightings and Preliminary Explanations, 1918-1938", Air Power History, 54, 2 (2007), p 18.

75. DOD Archives, WW1 WD, Box 1, Air 1/1247/204/7/1, Vol. 10, Aviation report on German South West Africa, April 1915-1916, Diary No. 2 kept by Lieutenant CareyThomas.

76. DOD Archives, WW1 WD, Box 1, Air 1/1247/204/7/1, Report by Major Wallace on the campaign in German South West Africa, 1915, 21 July 1916; DOD Archives, WW1 WD, Box 1, Air 1/1247/204/7/1, Vol 10, Aviation report on German South West Africa, April 1915-1916, Diary No. 2 kept by Lieutenant Carey-Thomas.

77. DOD Archives, SD, Box 252, 17138, Reports of Force Commanders in German South West Africa, Despatch No. 4 by General Botha covering the period 15 May to 18 July 1915; L’ange, Urgent Imperial Service, p 264. 
The UDF advanced in the face of the retreating German forces with the immediate objectives of capturing Omaruru and Kalkveld. The concept of "find, fix and destroy" was complicated by the mobile retreat of the German forces. The aerial reconnaissance facilitated the "find" function of the UDF's ground operations, however the chances of battle were negated by the German decision to avoid combat. Botha was aware of the dilemma and in June 1915 he mentioned it to Smuts in formal correspondence. The prime minister also added that he doubted very much whether the Germans at Kalkveld would offer battle because they had previously abandoned well prepared defensive positions in favour of their retreat. ${ }^{78}$ Botha added that he was unable to stop the Germans from retreating because of the geography of GSWA, however if they decided to fight it would be likely that a decisive result would be achieved. ${ }^{79}$

Wallace and an aviation team advanced to Omaruru with Brits and arrived on 18 June 1915. They then proceeded to finalise the preparation of the aerodrome at Omaruru which the Germans had started constructing (for their own aircraft) before abandoning the site. Subsequently Hinchelwood and Creed arrived at Karibib on 18 June after taking a two-hour flight from Walvis Bay. ${ }^{80}$ The construction of aerodromes along the axis of advance allowed for the projection of airpower throughout the operational theatre. The supporting elements of the Aviation Corps had 22 cars (in total) which were used to transport personnel and spares between the required points on the axis of advance and the lines of communication. ${ }^{81}$

While the SAAC moved forward on the lines of communication, Brits and Myburgh's forces commenced their extensive pincer envelopments to the northwest and northeast respectively. The double envelopment was designed to cut off the German retreat.82 The 1st Mounted Brigade captured Omaruru on 19 June 1915.83 Creed flew up from Karibib to Omaruru on 19 June, where he joined up with Wallace and his team. Three Henri Farman planes were deployed at the front and 30 men under

78. DOD Archives, SD, Box 252, 17138, Reports of Force Commanders in German South West Africa, Despatch No. 4 by General Botha covering the period 15 May to 18 July 1915.

79. TNA, War Cabinet (hereafter CAB) 45/112, The Campaign in German South West Africa. 1914-1918, Narrative of Events, 21 June 1915.

80. DOD Archives, WW1 WD, Box 1, Air 1/1247/204/7/1, Vol. 10, Aviation report on German South West Africa, April 1915-1916, Diary No. 2 kept by Lieutenant CareyThomas; DOD Archives, WW1 WD, Box 1, Air 1/1247/204/7/1, Vol. 3, Aviation report on German South West Africa, April 1915-1916, War Diary; DOD Archives, WW1 WD, Box 1, Air 1/1247/204/7/1, Report by Major Wallace on the campaign in German South West Africa, 1915, 21 July 1916.

81. DOD Archives, WW1 WD, Box 1, Air 1/1247/204/7/1, Vol. 2, Aviation report on German South West Africa, April 1915-1916, Report of Transport Officer.

82. DOD Archives, SD, Box 252, 17138, Reports of Force Commanders in German South West Africa, Despatch No. 4 by General Botha, covering the period 15 May to 18 July 1915.

83. Ritchie, With Botha in the Field, p 55. Whittal gives the date as 20 June, see With Botha and Smuts in Africa, p 104. 
Turner and Emmet remained at Walvis Bay. ${ }^{84}$ Cripps crashed his plane on landing at Karibib on 20 June, ${ }^{85}$ and it had to be returned by train to the aviation workshop in Walvis Bay. 86

Five reconnaissance flights were conducted over Kalkveld and Waterberg from Karibib and Omaruru. ${ }^{87}$ Two reconnaissance flights detailed 500 German troops present on 21 June who were deployed in a semicircle at Kalkveld, ${ }^{88}$ and on 22 June a reconnaissance flight reported 150 German troops present in the same position. ${ }^{89}$ Two more reconnaissance flights on 23 June were taken over Waterberg and Kalkveld where no German troops were found. ${ }^{90}$ Botha stated that the German forces' strength at Kalkveld was known prior to the advance which gave the UDF confidence. ${ }^{91}$

A further reconnaissance was done by Van der Spuy and Wallace on the morning of 24 June, which was the date for the UDF advance on Kalkveld, with the aim of determining possible locations for aerial bombardments. ${ }^{92}$ During the aerial reconnaissance the German forces were spotted about 56 kilometres northeast of Kalkveld. ${ }^{93}$ Wallace's reconnaissance flight observed Manie Botha's forces deploying in a "V" formation but no German forces were spotted in their defensive positions. ${ }^{94}$

84. DOD Archives, WW1 WD, Box 1, Air 1/1247/204/7/1, Report by Major Wallace on the campaign in German South West Africa, 1915, 21 July 1916.

85. DOD Archives, WW1 WD, Box 1, Air 1/1247/204/7/1, Vol. 3, Aviation report on German South West Africa April 1915-1916, War Diary; DOD Archives, WW1 WD, Box 1, Air 1/1247/204/7/1, Vol. 10, Aviation report on German South West Africa, April 1915-1916, Diary No. 2 kept by Lieutenant Carey-Thomas.

86. DOD Archives, WW1 WD, Box 1, Air 1/1247/204/7/1, Report by Major Wallace on the campaign in German South West Africa, 1915, 21 July 1916.

87. DOD Archives, WW1 WD, Box 1, Air 1/1247/204/7/1, Report by Major Wallace on the campaign in German South West Africa, 1915, 21 July 1916.

88. DOD Archives, SD, Box 252, 17138, Reports of Force Commanders in German South West Africa, Despatch No. 4 by General Botha, covering the period 15 May to 18 July 1915; DOD Archives, WW1 WD, Box 1, Air 1/1247/204/7/1, Vol. 3, Aviation report on German South West Africa, April 1915-1916, War Diary.

89. DOD Archives, WW1 WD, Box 1, Air 1/1247/204/7/1, Report by Major Wallace on the campaign in German South West Africa, 1915, 21 July 1916; DOD Archives, WW1 WD, Box 1, Air 1/1247/204/7/1, Vol. 3, Aviation report on German South West Africa April 1915-1916, War Diary.

90. DOD Archives, WW1 WD, Box 1, Air 1/1247/204/7/1, Vol. 3, Aviation report on German South West Africa, April 1915-1916, War Diary.

91. DOD Archives, SD, Box 252, 17138, Reports of Force Commanders in German South West Africa, Despatch no. 4 by General Botha, 15 May to 18 July 1915.

92. DOD Archives, WW1 WD, Box 1, Air 1/1247/204/7/1, Report by Major Wallace on the campaign in German South West Africa, 1915, 21 July 1916; DOD Archives, WW1 WD, Box 1, Air 1/1247/204/7/1, Vol. 3, Aviation report on German South West Africa, April 1915-1916, War Diary.

93. DOD Archives, WW1 WD, Box 1, Air 1/1247/204/7/1, Vol. 3, Aviation report on German South West Africa April 1915-1916, War Diary.

94. DOD Archives, WW1 WD, Box 1, Air 1/1247/204/7/1, Report by Major Wallace on the campaign in German South West Africa, 1915, 21 July 1916. 
Manie Botha's 3rd Mounted Brigade took Kalkveld unopposed on 24 June. ${ }^{95}$ The Germans allegedly retreated as a result of the threat from Botha's flanking movements. ${ }^{96}$ Wallace proceeded to Kalkveld by road where he inspected the aerodrome there and ordered the aircraft up from Omaruru. ${ }^{97}$

On his arrival at Kalkveld on 25 June 1915, Van der Spuy crashed his aeroplane but survived with minor injuries. ${ }^{98}$ The aircraft was subsequently repaired once spare parts were brought up from Walvis bay. ${ }^{99}$ Wallace moved to Otjitasu accompanying the Union's advance where he found a suitable aerodrome and by 28 June two Henri Farman's were sent to the forward base from where further reconnaissance flights were conducted on the Germans' final defensive positions. ${ }^{100}$

The extension of the lines of communication, which was a result of the UDF's advance, placed a strain on the entire UDF, including the SAAC because the aeroplane spares and logistics took a considerable time to get to the front. In the course of the advance an aerodrome was found at Brakpan and was used as a launching base for reconnaissance flights towards Otavi. On 29 June Hinshelwood and Creed each carried out reconnaissance flights towards Otavi during which both pilots came under fire from German troops and despite the German fire, both pilots successfully dropped their eight-bomb payload on the German position, hitting trains and troops. ${ }^{101}$

The German forces were now on the back foot and prepared defensive positions on the Otavi - Tsumeb line. The German officers, Major H. Ritter and Capt H.O. von Kleist were placed in charge of delaying the UDF. Ritter and his force were deployed at Otavifontein and Von Kleist was deployed between Otavi and Grootfontein. ${ }^{102}$

95. DOD Archives, SD, Box 252, 17138, Reports of Force Commanders in German South West Africa, Despatch No 4 by General Botha covering the period 15 May to 18 July 1915.

96. TNA, CAB 45/112, The Campaign in German South West Africa 1914-1918, Narrative of Events, 24 June 1915.

97. DOD Archives, WW1 WD, Box 1, Air 1/1247/204/7/1, Report by Major Wallace on the campaign in German South West Africa, 1915, 21 July 1916.

98. Van der Spuy, Chasing the Wind, p 81.

99. DOD Archives, WW1 WD, Box 1, Air 1/1247/204/7/1, Vol. 3, Aviation report on German South West Africa, April 1915-1916, War Diary; DOD Archives, WW1 WD, Box 1, Air 1/1247/204/7/1, Vol. 10, Aviation report on German South West Africa, April 1915-1916, Diary No. 2 kept by Lieutenant Carey-Thomas.

100. DOD Archives, WW1 WD, Box 1, Air 1/1247/204/7/1, Report by Major Wallace on the campaign in German South West Africa, 1915, 21 July 1916.

101. TNA, CAB 45/112, The Campaign in GSWA, 1914-1918, Narrative of Events, 1 July 1915; DOD Archives, WW1 WD, Box 1, Air 1/1247/204/7/1, Vol. 3, Aviation report on GSWA April 1915-1916, War Diary; DOD Archives, WW1 WD, Box 1, Air $1 / 1247 / 204 / 7 / 1$, Report by Major Wallace on the campaign in German South West Africa, 1915, 21 July 1916; DOD Archives, WW1 WD, Box 1, Air 1/1247/204/7/1, Vol. 10, Aviation report on German South West Africa, April 1915-1916, Diary No. 2 kept by Lieutenant Carey-Thomas; DOD Archives, SD, Box 252, 17138, Reports of Force Commanders in German South West Africa, Despatch No. 4 by General Botha covering the period 15 May to 18 July 1915.

102. L'ange, Urgent Imperial Service, p 288. 
On 30 June a reconnaissance flight was sent out to Otavi which dropped its payload on the German position. A subsequent flight was sent out to determine the location of Myburgh's forces that had lost contact with Botha. ${ }^{103}$ The intelligence report provided no concrete information on the location of the 2nd Mounted Brigade but unequivocally confirmed the presence of German forces in and around Otavi and Otavifontein. Botha and the Union forces departed for Otavi and Otavifontein on the night of 30 June and carried out the advance through to the early hours of 1 July 1915. ${ }^{104}$ Manie Botha led the attack on the German position at Otavifontein ${ }^{105}$ and following a brief engagement, the Germans forces withdrew to Grootfontein. ${ }^{106}$ Map 2 indicates the advance on Otavifontein.

103. DOD Archives, SD, Box 252, 17138, Reports of Force Commanders in GSWA, Despatch No. 4 by General Botha covering the period 15 May to 18 July 1915; DOD Archives, WW1 WD, Box 1, Air 1/1247/204/7/1, Vol. 3, Aviation report on German South West Africa April 1915-1916, War Diary; Garcia, “A Manoeuvre Warfare Analysis”, p 109.

104. DOD Archives, SD, Box 252, 17138, Reports of Force Commanders in GSWA, Despatch No. 4 by General Botha, 15 May to 18 July 1915; Collyer, The Campaign in German South West Africa, 1914-1915, p 137; L'ange, Urgent Imperial Service, p 291; Whittal, With Botha and Smuts in Africa, p 147.

105. DOD Archives, SD, Box 252, 17138, Reports of Force Commanders in GSWA, Despatch No. 4 by General Botha, 15 May to 18 July 1915; Ritchie, With Botha in the Field, p 59.

106. TNA, CAB 45/112, Campaign in GSWA 1914-1918, Narrative of Events, 3 July 1915. 


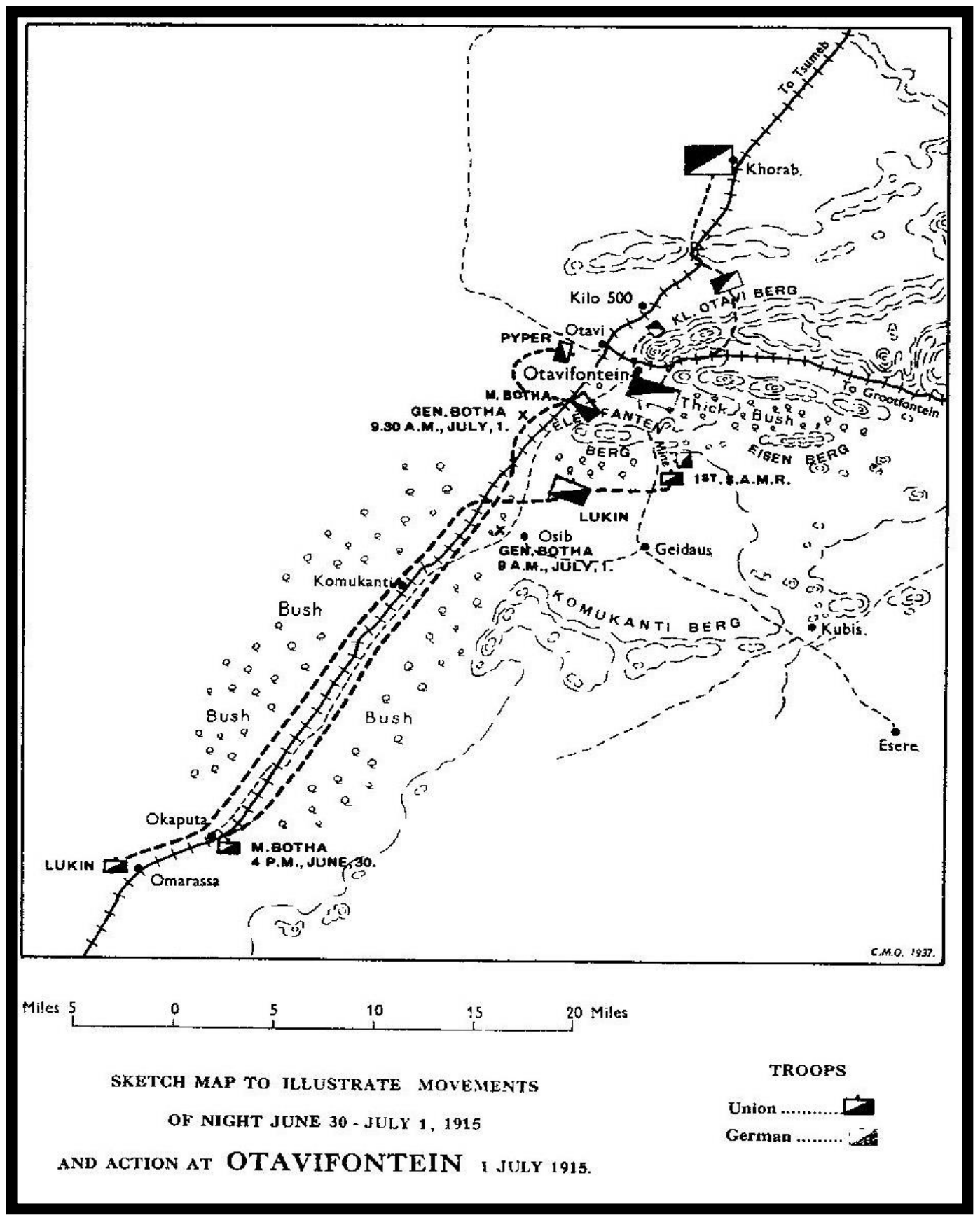

\section{Map 2: Advance on Otavifontein 107}

The 1st and 2nd Mounted Brigades advanced on Namutoni and Grootfontein respectively. The pincer envelopments were aimed at cutting off the retreat of the German forces. ${ }^{108}$ The main German force withdrew to Khorab where the final surrender took place. ${ }^{109}$

107. Collyer, The Campaign in German South West Africa, 1914-1915, opposite p 137.

108. DOD Archives, SD, Box 252, 17138, Reports of Force Commanders in German South West Africa, Despatch No. 4 by General Botha covering the period 15 May to 18 July 1915.

109. Anon., Official History, p 46. 
On 1 July 1915, Creed conducted a reconnaissance and aerial bombardment of the German forces at Khorab. An aerial reconnaissance on 5 July located German forces in and around Tsumeb. The reconnaissance flight doubled up as an aerial bombing mission where the aircraft fired its payload. ${ }^{110}$ The reconnaissance aimed to facilitate ground operations by confirming the final location of German forces.

The 2nd Mounted Brigade advanced on Tsumeb in early July after which they took the town unopposed on 6 July 1915.111 Brits and the 1st Mounted Brigade captured Namutoni on 8 July where the German forces surrendered.112 The UDF effectively outmanoeuvred and encircled the German forces in GSWA. The German forces in GSWA officially capitulated at 02:00 on 9 July 1915,113 with approximately 4 000 troops and 30 guns. ${ }^{114}$

\section{Analysis and conclusion}

The UDF made use of aeroplanes for reconnaissance and rudimentary aerial bombardment during the Union of South Africa's First World War campaign in GSWA. The arrival of aeroplanes in the theatre of operations on 1 May 1915 allowed for the Union of South Africa's first deployment of military aeroplanes in conventional operations.

The use of aircraft allowed the UDF to "find" the German forces which facilitated the mobile UDF elements attempts to "fix" the German forces by enveloping manoeuvres. The Germans traded space for time with their numerically inferior forces and constantly retreated. The UDF finally managed to surround the German forces completely at Khorab, inducing their surrender.

The use of aeroplanes allowed the UDF commanders to understand the intelligence picture better and this facilitated the deployment of the Union's forces (refer to Table 1). Knowledge of the location of the German forces expedited the timely execution of the operational plan and the battle concept.

110. DOD Archives, WW1 WD, Box 1, Air 1/1247/204/7/1, Report by Major Wallace on the campaign in German South West Africa, 1915, 21 July 1916; DOD Archives, WW1 WD, Box 1, Air 1/1247/204/7/1, Vol. 10, Aviation report on German South West Africa, April 1915-1916, Diary 2 kept by Lieutenant Carey-Thomas.

111. TNA, CAB 45/112, The Campaign in German South West Africa 1914-1918, Narrative of Events, 8 July 1915; Anon., Official History, p 40. Whittal says that the South African forces were ready to attack Tsumeb on 5 July and the town subsequently surrendered. See Whittal, With Botha and Smuts in Africa, p 152.

112. Meintjes, General Louis Botha, p 269.

113. DOD Archives, SD, Box 252, 17138, Reports of Force Commanders in German South West Africa, Despatch No. 4 by General Botha covering the period 15 May to 18 July 1915; Meintjes, General Louis Botha, p 262; Trew, Botha Treks, p 175.

114. Meintjes, General Louis Botha, p 262; Trew, Botha Treks, p 175. 
There were two reconnaissance flights taken over Omaruru prior to the UDF's advance. These flights confirmed the German withdrawal from their defensive positions and allowed the Union forces to advance with confidence and speed. The UDF advanced on Omaruru on 18 June and captured it on 19 June 1915.

After Omaruru, the next position on the UDF's advance was Kalkveld and five reconnaissance flights were conducted which determined the presence of German forces there from 21 to 23 June 1915. The UDF subsequently took Kalkveld unopposed on 24 June. Following the capture of Kalkveld the Aviation Corps reconnoitred Otavi and confirmed the presence of German forces on 29 and 30 June 1915. The UDF then advanced on Otavi during the night of 30 June arriving on 1 July 1915, after which the UDF engaged elements of the German force who in turn made a fighting withdrawal. The final positions of Khorab and Tsumeb were aerially reconnoitred on 1 and 5 July 1915 respectively before the German forces were completely and effectively enveloped and forced to surrender on 9 July $1915 .{ }^{115}$

\begin{tabular}{|c|c|c|c|c|c|}
\hline \multicolumn{6}{|c|}{$\begin{array}{c}\text { Aerial Reconnaissance and Bombing } \\
\text { Operations }\end{array}$} \\
\hline Area of operations & Date & $\begin{array}{l}\text { Number of } \\
\text { operational } \\
\text { flights }\end{array}$ & $\begin{array}{l}\text { Reconnaissance } \\
\text { flights }\end{array}$ & $\begin{array}{l}\text { Reconnaissance } \\
\text { and bombing } \\
\text { flights }\end{array}$ & $\begin{array}{l}\text { Outcome in terms of ground } \\
\text { action }\end{array}$ \\
\hline Omaruru & $\begin{array}{r}28-\text { May- } \\
15 \\
\end{array}$ & 1 & 1 & 0 & Intelligence picture amended \\
\hline Omaruru & 10-Jun-15 & 1 & 0 & 1 & $\begin{array}{l}\text { Omaruru was taken by } 19 \text { June } \\
1915\end{array}$ \\
\hline Kalkveld & 21-Jun-15 & 2 & 2 & 0 & Intelligence picture amended \\
\hline Kalkveld & 22-Jun-15 & 1 & 1 & 0 & Intelligence picture amended \\
\hline Kalkveld & 23-Jun-15 & 2 & 2 & 0 & Intelligence picture amended \\
\hline Kalkveld & 24-Jun-15 & 2 & 2 & 0 & $\begin{array}{l}\text { Determined locations for aerial } \\
\text { bombardment }\end{array}$ \\
\hline Otavi & 29-Jun-15 & 2 & 0 & 2 & $\begin{array}{l}\text { Confirmed the presence of } \\
\text { German forces Intelligence } \\
\text { picture amended }\end{array}$ \\
\hline Otavi & 30-Jun-15 & 1 & 0 & 1 & $\begin{array}{l}\text { Advance on Otavi on } 30 \text { June } \\
1915\end{array}$ \\
\hline Khorab & 01-Jul-15 & 1 & 0 & 1 & Intelligence picture amended \\
\hline Tsumeb & 05-Jul-15 & 1 & 0 & 1 & Intelligence picture amended \\
\hline & & 14 & 8 & 6 & \\
\hline
\end{tabular}

Table 1: Aerial reconnaissance and bombing operations in GSWA 116

115. TNA, CAB 45/112, The Campaign in German South West Africa 1914-1918, Narrative of Events, 9 July 1915.

116. DOD Archives, WW1 WD, Box 1, Air 1/1247/204/7/1, Vol. 10, Aviation report on German South West Africa, April 1915-1916, Diary No. 2 kept by Lieutenant CareyThomas; DOD Archives, WW1 WD, Box 1, Air 1/1247/204/7/1, Vol 3, Aviation report 
Aerial operations in the GSWA campaign comprised 14 flights in direct support of ground operations (refer to Table 1 and Graph 1). The flights provided the UDF command with reconnaissance which assisted in their decision making process in terms of where and when to deploy. Botha was of the opinion that current intelligence of where the German force was positioned allowed the UDF to deploy with the minimum required number of troops. ${ }^{117}$ The concept of advancing with a given amount of troops relates to the availability of logistics to keep one's own forces in the field and the availability of real time intelligence of enemy quantities and positions.

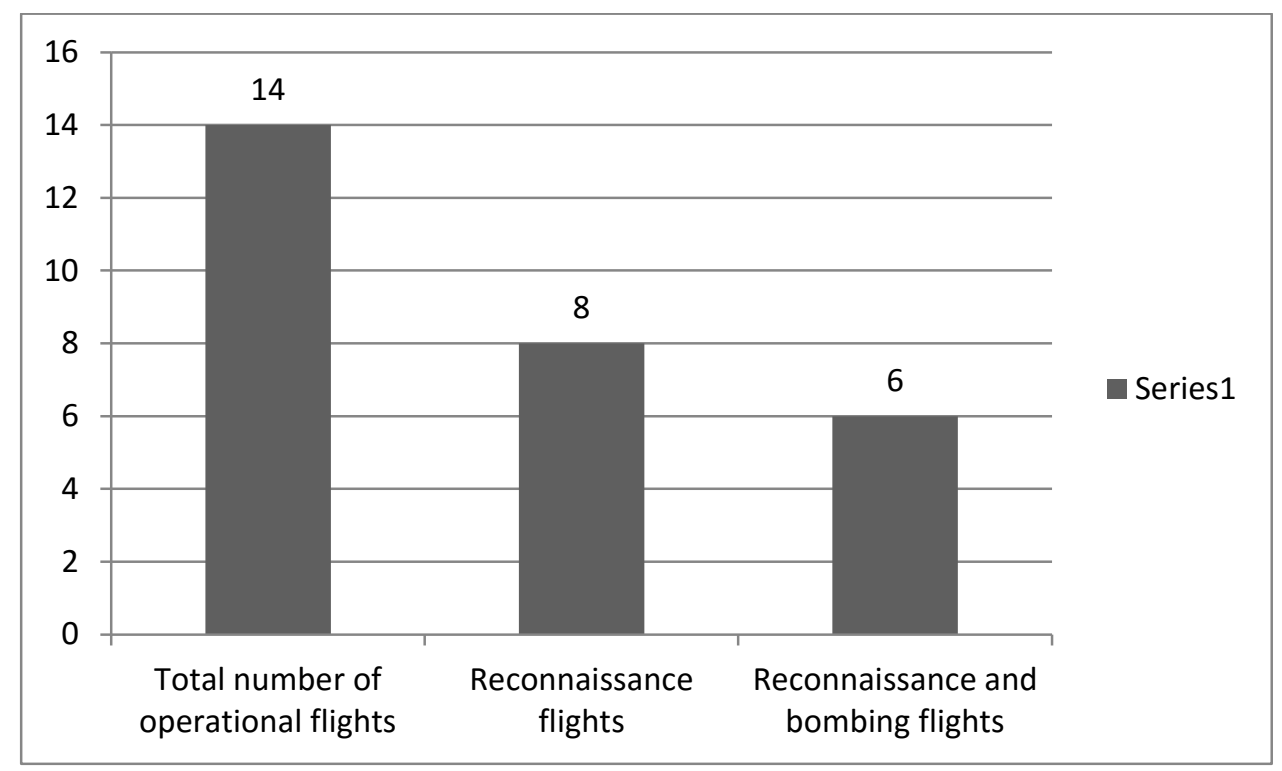

Graph 1: Aerial reconnaissance and bombing operations in GSWA ${ }^{118}$

Botha gives credit to his subordinate commanders in the execution of their sweeping envelopments of the German forces and describes the reason for the rapid victory as the impact of surprise on the German forces. ${ }^{119}$ The final advance commenced on 18 June, after which Omaruru was taken on 19 June, followed by Kalkveld on 24 June and Otavi on 1 July 1915. Because the German positions

on German South West Africa, April 1915-1916, War Diary; DOD Archives, WW1 WD, Box 1, Air 1/1247/204/7/1, Report by Major Wallace on the campaign in German South West Africa, 1915, 21 July 1916.

117. DOD Archives, SD, Box 252, 17138, Reports of Force Commanders in German South West Africa, Despatch No. 4 by General Botha covering the period 15 May to 18 July 1915.

118. DOD Archives, WW1 WD, Box 1, Air 1/1247/204/7/1, Vol. 10, Aviation report on German South West Africa, April 1915-1916, Diary No. 2 kept by Lieutenant CareyThomas; DOD Archives, WW1 WD, Box 1, Air 1/1247/204/7/1, Vol. 3, Aviation report on German South West Africa, April 1915-1916, War Diary; DOD Archives, WW1 WD, Box 1, Air 1/1247/204/7/1, Report by Major Wallace on the campaign in German South West Africa, 1915, 21 July 1916.

119. DOD Archives, World War 1, German South West Africa (hereafter WW1 GSWA), Box 23a, Citations, German South West Africa, Northern Army, Commander of the 1st Mounted Brigade Special Appointments, 17 February 1918. 
(mentioned above) were captured by the UDF, the Aviation Corps advanced with the ground forces and prepared aerodromes at the respective positions which allowed for the forward projection of airpower throughout the advance (refer to Graph 2). The number of aerial reconnaissance flights increased in line with the requirements of the UDF's advance.

\section{Operational flights during the final advance}

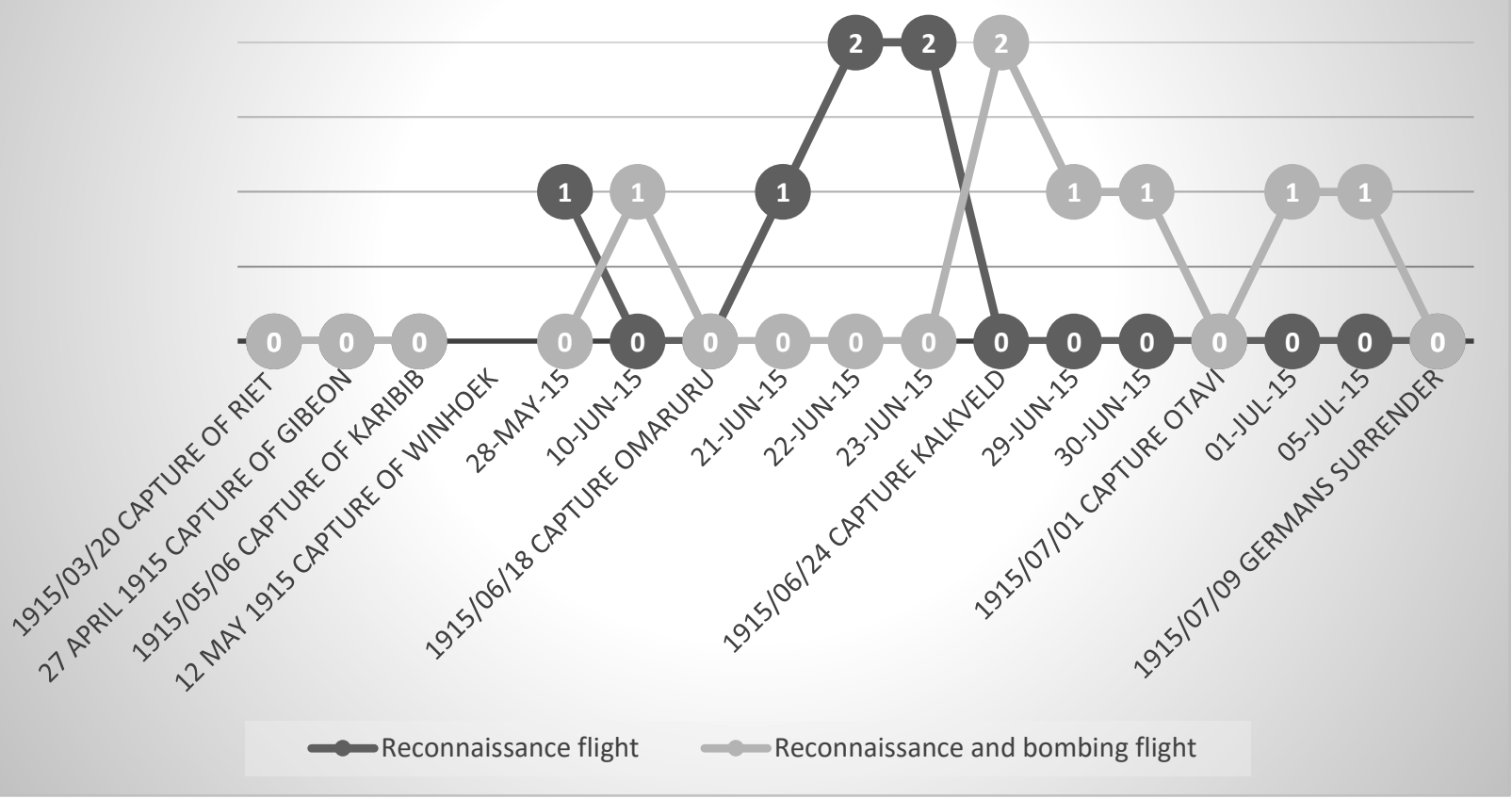

\section{Graph 2: Operational flights during the final advance ${ }^{120}$}

Van Der Spuy states that according to Botha and Collyer, the use of aircraft had assisted in shortening the campaign considerably.121 Botha was reportedly quite impressed by the value of aeroplanes in warfare and mentioned that every support should be given to developing the use of aviation in combat. ${ }^{122}$

Following the culmination of the German South West African campaign the SAAC went on to become 26 Squadron of the Royal Air Force and served in the German East African campaign and on the Western Front. Van der Spuy served with distinction in both World Wars and retired with the rank of major general.

120. DOD Archives, WW1 WD, Box 1, Air 1/1247/204/7/1, Vol. 10, Aviation report on German South West Africa April 1915-1916, Diary No. 2 kept by Lieutenant CareyThomas; DOD ArchiveWW1 WD, Box 1, Air 1/1247/204/7/1, Vol. 3, Aviation report on German South West Africa, April 1915-1916, War Diary; DOD Archives, WW1 WD, Box 1, Air 1/1247/204/7/1, Report by Major Wallace on the campaign in German South West Africa, 1915, 21 July 1916.

121. Van der Spuy, Chasing the Wind, p 82; L'ange, Urgent Imperial Service, p 273.

122. Ritchie, With Botha in the Field, p 56. 


\section{REFERENCES}

Anon., Union of South Africa and the Great War, 1914-1918: Official History (Government Printer, Pretoria, 1924).

Baucom, D.R., "Wakes of War: Contrails and the Rise of Air Power, 1918-1945, Part 1, Early Sightings and Preliminary Explanations, 1918-1938", Air Power History, 54, 2 (2007).

Bisset, W.M., "Unexplored Aspects of South Africa's First World War History”, Scientia Militaria, 6, 3 (1976).

Blount, C., "Modern Airpower and the 1916 Arab Revolt: What can the Modern Airman Do to Counter Lawrence of Arabia", Air and Space Power Journal, 23, 3 (2009).

Collyer, J.J., The Campaign in German South West Africa, 1914-1915 (Government Printer, Pretoria, 1937).

Couzens, T., The Great Silence (Sunday Times, Johannesburg, 2014).

Cruise, A., Louis Botha's War: The Campaign in German South West Africa, 1914-1915 (Zebra Press, Cape Town, 2015).

Dane, E., British Campaigns in Africa and the Pacific, 1914-1918 (Hodder \& Stoughton, London, 1919).

Delport, A., '"Boks and Bullets, Coffins and Crutches': An Exploration of the Body, Mind and Places of 'Springbok' South African Soldiers in the First World War", MA dissertation, Stellenbosch University, 2015.

Difford, I.D., The Story of the 1st Battalion Cape Corps, 1915-1919 (Hortons, Cape Town, 1920).

Dedering, T., "Air Power in South Africa, 1914-1939”, Journal of Southern African Studies, 31, 3 (2015).

Dorning, W.A., "A Concise History of the South African Defence Force, 1912-1987", Militaria, South African Journal for Military Studies, 17, 2 (1987).

Epstein, K.P., "Imperial Airs: Leo Amery, Airpower and Airpower, 1873-1945", The Journal of Imperial and Commonwealth History, 38, 4 (2010).

Farwell, B., The Great War in Africa, 1914-1918 (Norton, New York, 1986).

Garcia, A., "A Manoeuvre Warfare Analysis of South Africa's 1914-1915 German South West African Campaign", Scientia Militaria, 45, 1 (2017).

Garcia, A., "Manoeuvre Warfare in the South African Campaign in German South West Africa during the First World War", MA dissertation, University of South Africa, 2015.

Gleeson, I., The Unknown Force: Black, Coloured and Indian Soldiers through the Two World Wars (Ashanti, Johannesburg, 1994).

Grundlingh, A.M., Fighting Their Own War: South African Blacks and the First World War (Ravan Press, Johannesburg, 1988).

Grundlingh, A.M., Participation and Remembrance: South African Black and Coloured Troops in the First World War, 1914-1918 (Sun Press, Stellenbosch, 2014).

Harvey, A.D., "Air Warfare in Perspective”, Air Power History, 60, 3 (2013).

Hennessy, J.A., "Men and Planes of World War 1 and the History of Lafayette Escadrille", Air Power History, 61, 2 (2014).

Killingray, D., 'The War in Africa', in Strachan, H. (ed.), The Oxford Illustrated History of the First World War (Oxford University Press, Oxford, 1998). 
Kleynhans, E., "A Critical Analysis of the Impact of Water on the South African Campaign in German South West Africa, 1914-1915", Historia, 61, 2 (2016).

L'ange, G., Urgent Imperial Service (Ashanti, Johannesburg, 1991).

Lukasik, S.H., "Insurgent Airpower in Historical Perspective: An Introduction and Prospectus of Research", The Historian, 74, 2 (2012).

Meintjes, J., General Louis Botha (Cassell \& Co., London, 1970).

Mahncke, J.O.E.O., "Aircraft Operations in the German Colonies, 1911-1916: The Fliegertruppe of the Imperial German Army", Military History Journal, 12, 2 (2001).

Monick, S., "The Third Man: Willy Trück and the German Air Effort in South West Africa in World War I", Military History Journal, 5, 3 (1981).

Morrow, J.H., "The War in the Air", in Strachan, H. (ed.), The Oxford Illustrated History of the First World War (Oxford University Press, Oxford, 1998).

Nasson, B., "Delville Wood and South African Great War Commemoration", English Historical Review, 119, 480 (2004).

Nasson, B., Springboks on the Somme (Penguin, Johannesburg, 2007).

Nasson, B., World War 1 and the People of South Africa (Tafelberg, Cape Town, 2014).

O'Shaughnessy, W.W. and Rayner, W.S., How Botha and Smuts Conquered German South West (Simpkin, London, 1916).

Paterson, H., "First Allied Victory: The South African Campaign in German South West Africa, 1914-1915", Military History Journal, 13, 2 (2004).

Raleigh, W.A. and Jones, H.A., The War in the Air: Being the Story of the Part Played in the Great War of the Royal Air Force (Clarendon Press, Oxford, 1922).

Reitz, D.E., Trekking On (Travel Book Club, London, 1947).

Ritchie, M.E., With Botha in the Field (Longmans, London, 1915).

Robinson, P.K.J., With Botha's Army (Allen \& Unwin, London, 1916).

Samson, A., Britain, South Africa and the East African Campaign, 1914-1918: The Union Comes of Age (I.B. Tauris, London, 2006).

Samson, A., World War I in Africa: The Forgotten Conflict among European Powers (I.B. Taurus, London, 2013).

Showalter, D.E., "Manoeuvre Warfare: The Eastern and Western Fronts", in Strachan, H. (ed.), The Oxford Illustrated History of the First World War (Oxford University Press, Oxford, 1998).

Steckfuss, J., Eyes All over the Sky: Aerial Reconnaissance in the First World War (Casemate, Oxford, 2016).

Stejskal, J., The Horns of the Beast: The Swakop River Campaign and World War I in South West Africa, 1914-1915 (Helion, Solihull, 2014).

Strachan, H., The First World War, Vol 1: To Arms (Oxford University Press, Oxford, 2001).

Swart, S., '“A Boer and his Gun and his Wife are Three Things Always Together': Republican Masculinity and the 1914 Rebellion", Journal of Southern African Studies, 24, 4 (2008).

Swart, S., "'Desperate Men' The 1914 Rebellion and the Polities of Poverty", South African Historical Journal, 42, 1 (2000).

Swart, S., "The Five Shilling Rebellion': Rural White Male Anxiety and the 1914 Boer Rebellion", South African Historical Journal, 56, 1 (2006).

Trew, H.F., Botha Treks (Blackie \& Son, London, 1936). 
Tidy, D.P., "They Mounted up as Eagles: A Brief Tribute to the South African Air Force”, The Military History Journal, 5, 6 (1982).

Ungleich, T.R., "The Defence of German South West Africa during World War I", MA thesis, University of Miami, 1974.

Van der Spuy, K.R., Chasing the Wind (Books of Africa, Cape Town, 1966).

Van der Waag, I., A Military History of Modern South Africa (Jonathan Ball, Johannesburg, 2015).

Van der Waag, I., “The Battle of Sandfontein, 26 September 1914: South African Military Reform and the German South West Africa Campaign, 1914-1915", First World War Studies, 4, 2 (2013).

Venter, A.I., Coloured: A Profile of Two Million South Africans in Cape Town (Human \& Rousseau, Cape Town, 1974).

Walker, H.F.B., A Doctor's Diary in Damaraland (Edward Arnold, London, 1917).

Warwick, R.C., "The Battle of Sandfontein: The Role and Legacy of Major General Sir Henry Timson Lukin", Scientia Militaria, South African Journal of Military Studies, 34, 2 (2006).

Whitmarsh, A., "British Army Manoeuvres and the Development of Military Airpower 1910-1913", War in History, 14, 3 (2007).

Williams, D., Springboks, Troepies and Cadres: Stories of the South African Army, 19122012 (Tafelberg, Cape Town, 2012).

Whittal, W., With Botha and Smuts in Africa (Cassell, London, 1917). 